\title{
Uptake of bone seeking radiotracer in the metastatic lymph node from testicular tumour
}

\author{
P Saisradha Patro, ${ }^{1}$ Kanhaiyalal Agrawal, ${ }^{1}$ Girish Kumar Parida, ${ }^{1}$ Dilip Kumar Parida ${ }^{2}$
}

'Department of Nuclear Medicine, All India Institute of Medical Sciences Bhubaneswar, Bhubaneswar, Orissa, India ${ }^{2}$ Department of Radiotherapy, All India Institute of Medical Sciences Bhubaneswar, Bhubaneswar, Orissa, India

Correspondence to Dr Kanhaiyalal Agrawal; nucmed_kanhaiyalal@ aiimsbhubaneswar.edu.in

Accepted 3 December 2021

\section{DESCRIPTION}

A 31-year-old man diagnosed with mixed germ cell tumour (GCT) of the left testis, had left para-aortic and left supraclavicular lymph node metastases (stage IIIA) at presentation. Post-left orchidectomy, he underwent a bone scintigraphy with technetium-99m methylene diphosphonate (Tc-99m MDP) for assessment of bone metastasis.

On planar whole-body Tc-99m MDP bone scan, there is a focus of increased osteoblastic activity in the L2 vertebra on the left side. Another focus of increased osteoblastic activity was seen in the left paravertebral region (arrow in figure 1). Rest of the bone scan shows physiological tracer uptake.

The single photon emission tomography integrated with computed tomography (SPECT-CT) of the lumbar region localises the uptake in the L2 vertebra to a lytic sclerotic lesion, confirming bone metastasis (arrows in A and B in figure 2 showing CT and fused SPECT-CT images, respectively). The left paravertebral focus corresponds to a large paraaortic soft tissue mass with areas of punctate calcification within, suggestive of a metastatic para-aortic lymph node (arrows in C and D in figure 2 showing CT and fused SPECT-CT images, respectively).

Testicular cancer is the most common solid malignancy in males within age group of 15-35 years and mixed GCT account for about 40\%-50\% of them. ${ }^{1}$ Synchronous metastasis to bone is common in patients with lung and para-aortic node metastases, with most common site being vertebra $(79 \%) .{ }^{23}$ Literature evidence suggests that primary

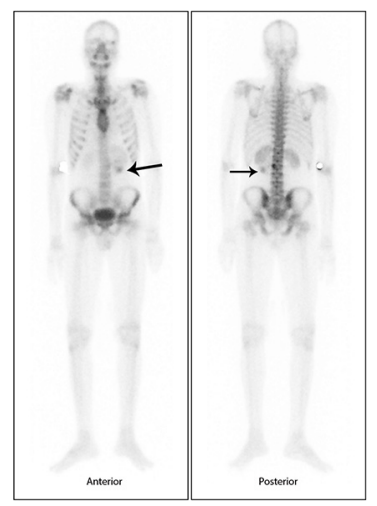

Figure 1 Planar whole-body technetium-99 m methylene diphosphonate (Tc-99m MDP) bone scan shows a focus of increased osteoblastic activity in the $\mathrm{L} 2$ vertebra on the left side. Another focus of increased osteoblastic activity is seen in the left paravertebral region (arrow). Rest of the bone scan shows physiological tracer uptake.
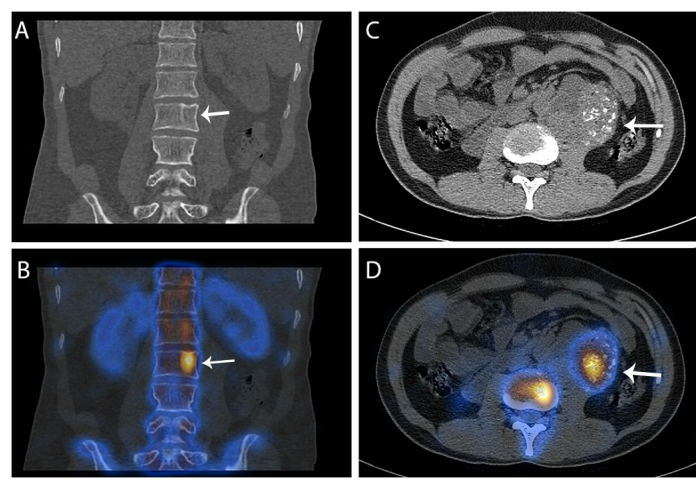

Figure 2 The single photon emission tomography integrated with computed tomography (SPECT-CT) of the lumbar region localises the uptake in the $\mathrm{L} 2$ vertebra to a lytic sclerotic lesion, confirming bone metastasis (arrows in A and B showing CT and fused SPECT-CT images, respectively). The left paravertebral focus corresponds to a large para-aortic soft tissue mass with areas of punctate calcification within, suggestive of a metastatic para-aortic lymph node (arrows in C and D showing CT and fused SPECT-CT images, respectively).

lymph node station for metastasis from left testicular tumour is left para-aortic and preaortic lymph nodes. ${ }^{4}$ The present case also shows lymph nodal metastatic patterns similar to as described in the literature. Mixed GCT of testis has both seminomatous and non-seminomatous component with bone metastasis having poor prognosis. Hence, bone scintigraphy is indicated for complete staging and prognostication. Extraosseous uptake of bone seeking radiotracers are seen in various benign and malignant lesions by different mechanisms. Different primary malignant as well as metastatic

Learning points

- Bone metastasis has poor prognosis in mixed germ cell tumour, hence bone scintigraphy has an important role in staging and prognostication.

- Technetium-99m methylene diphosphonate uptake in the metastatic lymph nodes is rare but possible due to ionic exchange on the crystalline surface of dystrophic calcification.

- Bone seeking radiotracer uptake in soft tissues in bone scan can mimic bone metastasis, hence single photon emission tomography integrated with computed tomography helps in differentiating between these two and changes management. 
lesions have shown dystrophic calcification and increased Tc-99m MDP uptake. ${ }^{5} 6$ The Tc-99m MDP uptake in these lesions is due to ionic exchange at the crystalline surface. ${ }^{7}$ There are only few publications describing bone seeking radiotracer uptake in metastatic lymph nodes of primary tumours like ureteral cancer and osteosarcoma. ${ }^{8} 9$ The present case is unique as it describes Tc-99m MDP uptake in the metastatic lymph node from testicular tumour. In the index case the uptake on planar scan mimics a blob of renal activity. However, these metastatic lymph nodes showing uptake in planar bone scan can mimic bone metastasis and SPECT-CT helps in differentiating the two which is important for prognostication. ${ }^{5}$

Contributors PSP: Conception, design of work, acquisition, analysis, interpretation of data, drafting, final approval. KA: Conception, design of work, interpretation of data, drafting, final approval. GKP: Conception, design of work, interpretation of data, drafting, final approval. DKP: interpretation of data, drafting, final approval.

Funding The authors have not declared a specific grant for this research from any funding agency in the public, commercial or not-for-profit sectors.

Competing interests None declared.

Patient consent for publication Consent obtained directly from patient(s).

Provenance and peer review Not commissioned; externally peer reviewed.
Case reports provide a valuable learning resource for the scientific community and can indicate areas of interest for future research. They should not be used in isolation to guide treatment choices or public health policy.

\section{REFERENCES}

1 Siegel R, Ward E, Brawley 0, et al. Cancer statistics, 2011: the impact of eliminating socioeconomic and racial disparities on premature cancer deaths. CA Cancer J Clin 2011;61:212-36.

2 Hitchins RN, Philip PA, Wignall B, et al. Bone disease in testicular and extragonadal germ cell tumours. Br J Cancer 1988;58:793-6.

3 Jamal-Hanjani M, Karpathakis A, Kwan A, et al. Bone metastases in germ cell tumours: lessons learnt from a large retrospective study. BJU Int 2013;112:176-81.

4 Kreydin El, Barrisford GW, Feldman AS, et al. Testicular cancer: what the radiologist needs to know. AJR Am J Roentgenol 2013;200:1215-25.

5 Wale DJ, Wong KK, Savas $\mathrm{H}$, et al. Extraosseous findings on bone scintigraphy using fusion SPECT/CT and correlative imaging. AJR Am J Roentgenol 2015;205:160-72.

6 Agrawal K, Bhattacharya A, Harisankar CNB, et al. F-18 fluoride uptake in calcified extraosseous metastases from ovarian papillary serous adenocarcinoma. Clin NuCl Med 2012;37:e22-3.

7 Peller PJ, Ho VB, Kransdorf MJ. Extraosseous Tc-99m MDP uptake: a pathophysiologic approach. Radiographics 1993;13:715-34.

8 Kaida H, Ishibashi M, Baba K, et al. Extraosseous uptake of metastatic lymph nodes of ureteral cancer on $99 \mathrm{Tcm}$ hydroxymethylene diphosphonate bone scintigraphy. $\mathrm{Br} J$ Radiol 2004;77:869-70.

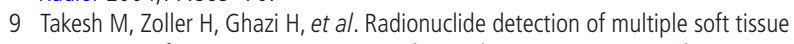
metastases of osteosarcoma masquerading as bone metastasis. Med Princ Pract 2012;21:582-4.

Copyright 2021 BMJ Publishing Group. All rights reserved. For permission to reuse any of this content visit https://www.bmj.com/company/products-services/rights-and-licensing/permissions/

BMJ Case Report Fellows may re-use this article for personal use and teaching without any further permission.

Become a Fellow of BMJ Case Reports today and you can:

- Submit as many cases as you like

- Enjoy fast sympathetic peer review and rapid publication of accepted articles

- Access all the published articles

Re-use any of the published material for personal use and teaching without further permission

Customer Service

If you have any further queries about your subscription, please contact our customer services team on +44 (0) 2071111105 or via email at support@bmj.com.

Visit casereports.bmj.com for more articles like this and to become a Fellow 